1 вчитель математики вищої категорії З3СО І-ІІІ ступенів № 9 ВЦА м. Торецьк Донецької області e-mail: inbib@ukr.net, ORCID 0000-0001-6012-074X

\title{
ВИКОРИСТАННЯ ПРАКТИЧНИХ РОБІТ НА УРОКАХ МАТЕМАТИКИ
}

Важлива умова вдосконалення викладання математики - посилення її практичної спрямованості. Одним із шляхів вирішення цього питання є формування в учнів практичних умінь та навичок. У статті розглядаються питання вдосконалення викладання математики шляхом впровадження в роботу практичних робіт. Висвітлюються різні форми і методи проведення таких робіт на уроках математики.

Ключові слова: шкілъний курс математики, прикладна спрямованість, практична робота

\section{Вступ}

На часі - нові кардинальні зміни в освіті. Усі ми ознайомлені з Концепцією реформування загальної середньої освіти «Нова українська школа». Цим документом передбачається масштабна конструктивна та змістовна перебудова української системи освіти, якісне наближення до європейських зразків. Серед головних задач освітян багато орієнтирів на розвиток в учнів активності та предметної компетентності. Важлива умова підвищення математичної компетентності учнів - посилення їі практичної спрямованості.

\section{Основна частина}

Однією з форм навчання математики, яка сприяе підвищенню цінних графічних і обчислювальних навичок і вмінь, необхідних для конструювання і практичної діяльності, є практичні роботи. Така форма роботи на уроках математики дозволяе учню усвідомити основні математичні залежності між величинами; ознайомитися з вимірювальними інструментами та їх застосуванням на практиці; встановити зв'язок між різними розділами курсу математики та іншими предметами [2].

При виконанні практичних завдань учні проводять міні дослідження, тобто долучаються до дослідницької діяльності: висувають гіпотезу, аналізують зв'язок між величинами, проводять порівняння і перевіряють гіпотезу, вчаться робити висновки. Використання у навчальній діяльності таких робіт формує навички застосовування отриманих знань на практиці і в повсякденному житті, розвиває пізнавальний інтерес до предмету, урізноманітнює навчальний процес, розкриває математику ні як абстрактну від повсякденного життя науку, а як прикладну науку для вирішення життєвих задач. 
На уроках математики необхідно пропонувати учням різні види самостійної діяльності. Здатність розмірковувати, аналізувати, будувати плани, створювати проєкти - дуже важливі вміння, які допоможуть у подальшому самостійно приймати рішення. Під самостійною навчальною роботою звичайно розуміють будь-яку організовану вчителем активну діяльність учнів, спрямовану на виконання поставленої мети в спеціально відведений для цього час [1]. Самостійна робота різноманітна за своїми видами і формами, але з точки зору внеску у формування ключових компетенцій виділяють такий її вид як практична робота.

Характерними особливостями практичних робіт є наступні:

- обчислювальна обробка результатів вимірювань за допомогою необхідних формул і порівняння результатів вимірювань і обчислень;

- використання креслярських, вимірювальних і обчислювальних інструментів, приладів;

- застосування таблиць, довідкової літератури;

- складання таблиць, які відображають функціональну залежність двох змінних величин того чи іншого процесу;

- побудова графіків.

Практичні роботи не тільки посилюють практичну спрямованість навчання, але і сприяють міцному, неформальному засвоєнню нового навчального матеріалу. До практичних занять слід віднести ті самостійні роботи учнів, які виконуються за допомогою спостережень, порівнянь, вимірювальних і обчислювальних інструментів, складання таблиць, побудови графіків з метою встановлення нових математичних закономірностей, понять. Найважливішою методичною проблемою, що вирішується в процесі виконання практичних робіт, є розвиток обчислювальної культури учнів.

Проведення практичних робіт включає в себе наступні етапи:

1. Постановка теми роботи і визначення мети.

2. Визначення порядку роботи або окремих $\dddot{11}$ етапів.

3. Безпосередне виконання роботи учнями та контроль вчителя за ходом занять і дотримання техніки безпеки.

4. Підведення підсумків роботи, формулювання основних висновків.

Факти, які учні отримують у результаті самостійної експериментальної роботи, довше утримуються в пам'яті та допомагають учням краще засвоїти складний теоретичний матеріал. Виконувати практичні роботи (завдання) можна індивідуально або групою. Індивідуальна робота формує уміння правильно, охайно й чітко виконувати малюнки, проводити обчислення. Групова робота формує ще й уміння і навички комунікативного характеру. 
Практичні роботи можуть бути організовані як у класі, так і задані додому. Залежно від обсягу та змісту матеріалу такий вид роботи може бути організований на цілий урок, на частину уроку або заданий у вигляді домашнього завдання (в останньому випадку на наступному уроці обговорюються результати, отримані учнями вдома). Перші практичні роботи в 5 класі бажано проводити тільки в класі. Вони повинні бути нетривалими, їх необхідно виконувати разом з учнями.

У 5-6 класах багато практичних робіт безпосередньо пов'язаних з геометричними темами: «Прямокутник і його площа», «Коло», «Кут. Види кутів. Побудова кута», «Масштаб», «Трикутник. Види трикутників», «Прямокутний паралелепіпед» та інші. Так, наприклад, в 6 класі при вивченні формул довжини кола, площі круга урок обов'язково проходить з використанням практичної роботи. Учні за допомогою звичайної нитки і лінійки вимірюють довжину кола, діаметр. Самостійно виконуючи ділення отриманих величин, приходять до висновку, що хоча кола були різними, відповідь виходить у всіх практично однаковою.

Таким чином, самостійно визначивши число «пі» і залежність між величинами, в учнів уже не виникають труднощі при розв'язуванні завдань, пов'язаних з формулами довжини кола і площі круга (Приклад 1).

6 клас

Тема. Довжина кола.

Мета. Виміряти довжину кола. Обчислити відношення довжин кіл до діаметрів. Визначити число $\pi$

Обладнання: циліндри або склянки різного діаметри (розміру), нитка, лінійка.

Хід роботи

1. Будуємо коло, радіус якого дорівнює 2 см.

2. Ставимо ручкою відмітку на нитці в тій точці, у якій нитка збігається зі своїм початком.

3. Розгортаємо нитку та вимірюємо їі довжину до відмітки. Ця довжина дорівнює довжині кола.
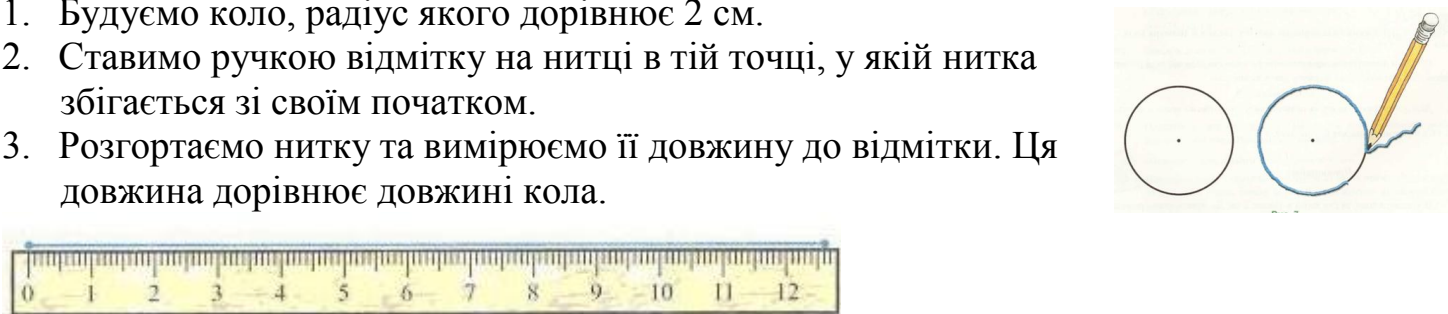

4. Виміряйте діаметри кіл даних фігур.

5. Обчисліть відношення довжин кіл до діаметрів.

\begin{tabular}{|c|c|c|}
\hline Довжина кола, $\mathbf{C}$ & Діаметр кола, $\mathbf{d}$ & $\begin{array}{l}\text { Відношення довжини } \\
\text { кола до діаметра, C/d }\end{array}$ \\
\hline & & \\
\hline & & \\
\hline
\end{tabular}

За скільки часу можна облетіти на літаку Землю вздовж екватора на висоті 10 км, рухаючись зі швидкістю 1200 км/год? Результат округліть до 0,1 год. (Радіус екватора наближено дорівнює 6370 км).

Рис. 1: Приклад 1 
Практичні роботи можуть бути проведеними на різних видах уроку. На уроці ознайомлення з новим матеріалом можуть бути проведені практичні роботи, після виконання яких можна висловити певне припущення, гіпотезу про залежність між величинами. Учням надається можливість самостійно зробити висновок про той або інший математичний факт.

Під час проведення уроку закріплення вивченого матеріалу можна запропонувати учням роботу, в якій вимагається застосувати знання для вирішення певного практичного завдання. Таким чином, учні згадують вже вивчені факти і застосовують їх на практиці.

Одним із засобів підвищення активності учнів є практичні роботи, пов'язані з побудовою моделі фігури: побудувати модель фігури, про яку йдеться в задачі, або використовувати для її розв'язування результати вимірів елементів даної моделі.

Як приклади можна навести в 5 класі тему «Прямокутний паралелепіпед. Куб. Піраміда»; в 11 класі «Піраміда. Дослідження положення висоти в деяких видах пірамід».

Перед початком роботи необхідно пояснити учням, скільки часу приділяється виконанню роботи, які вимоги до її оформлення. До кожної роботи складено опис, в якому зазначені: тема, мета роботи, назва необхідного обладнання, інструменти, схема оформлення.

\section{Висновки}

При виконанні практичних завдань на уроках математики учні вчаться робити логічні висновки, розвивають інтуїцію, отримують навички експериментальної роботи, розвивають уміння поводитися з приладами, самостійно робити висновки до отриманих дослідних даних, вчаться працювати з інтерактивними моделями. Це дозволяє більш глибоко і повно засвоювати теоретичний матеріал.

Проведення практичних робіт з учнями урізноманітнює уроки математики; підвищує активність і самостійність учнів на уроці; сприяють підвищенню якості знань учнів з математики; робить абстрактні теоретичні положення зрозумілими, доступними, наочними.

Під час правильно організованої роботи виховується культура праці (вміння організувати робоче місце, утримувати його й інструменти в порядку). Витончено виконана робота сприяє розвитку почуття краси, задоволеності від виконаної роботи. 


\section{Література}

1. Бевз Г.П. Методи навчання математики. Х.: Видавнича група «ОсноBa», 2003.

2. Васильева Д.В. Математика. 6 клас: Розробки уроків та методичні рекомендації. К.: Видавничий дім «Освіта», 2017.

3. Козловсъка О. Прикладна спрямованість шкільного курсу математики. Математика. 2008. № 3.

4. Король Я.А. Формування практичних умінь і навичок на уроках математики. Тернопіль: «Навчальна книга - Богдан», 2000. 136 с.

5. Пометун О.І., Пироженко Л.В. Сучасний урок: Інтерактивні технології навчання. К.: «Видавництво А.С.К.», 2004.

6. Розов Н. Х., Савін А. П. Лабораторні роботи з геометрії? Так! Математика в школі. 1994. № 6.

\section{I.V. Bibikova}

Institution of General Secondary Education №9, Toretsk, Donetsk region, Ukraine.

\section{Use of practical tasks at Mathematic lessons}

The important requirement of mathematics teaching improving is the reinforcement of its practical orientation. One way of resolving this issue is having pupils acquire some practical skills and abilities. This article comprises the questions of improving math teaching by introducing to the work process some practical assignments. The different forms and methods of holding such works at mathematics lessons are also considered here.

Keywords: school mathematics course, applied orientation, practical assignments. 